\title{
The FOMC in 1985: Reacting to Declining M1 Velocity
}

\author{
R. W. Hafer
}

NE of the most important issues influencing the formation of monetary policy by the Federal Open Market Committee (hereafter "Committee" or "FOMC") in 1985 was the unexpected and sizable decline of M1 velocity. Although M1 growth surged in 1985, doubling its 1984 growth rate, and inflation remained in check, real economic activity increased at a sluggish pace.' In response to this apparent change in the money-income relationship, the Committee rebased the $1985 \mathrm{M}$ growth target from IV/1984 to II/1985 and placed more than usual emphasis on judging the appropriateness of $M 1$ growth against the behavior of the broader aggregates (M2 and M3) and economic conditions.

R. W. Hafer is a research officer at the Federal Reserve Bank of St Louis. Thomas A. Pollmann provided research assistance.

Note: Citations referred to as "Record" are to the "Record of Policy Actions of the Federal Open Market Committee ${ }^{x}$ found in various issues of the Federal Reserve Bulletin. Citations referred to as "Report" are to the "Monetary Policy Report to the Congress," also found in various issues of the Federal Reserve Bulletin.

'For example, M1 growth from IV/1984 to $\mathrm{V} / 1985$ was 11.6 percent, compared with 5.2 percent for the IV/1983-IV/1984 period. Inflation during 1985 was 3.4 percent, slightly less than the 3.6 percent rate for 1984. Real GNP growth - GNP growth adjusted for infiation -.m for these same two periods averaged 2.2 percent and 5.8 percent. it should be noted that all data used in this article are those available to the Committee at the time of its deliberations. Consequently, data on real economic activity and inflation for the first three quarters of 1985 are based on 1972 prices, while fourth-quarter data use the recently revised series, based on 1982 prices. Because of the revision to the national income and product accounts, released on December 20, 1985, annual 1985 figures for real economic growth are based on an average of original and revised data.
This article examines the Committee's monetary policy decisions during 1985. In doing so, it discusses the factors that the Committee believed were important and the enviromment in which policy decisions were made.

\section{W}

Under the requirements of the Full Employment and Balanced Growth Act of 1978 - the HumphreyHawkins Act - the Committee semiannually reports to Congress on its annual growth rate objectives for monetary and credit aggregates. These reports are submitted in February, to establish the Committee's annual growth targets for the current year, and again in July, to review the progress made toward meeting those objectives and provide provisional growth ranges for the upcoming year. The period usually covered by the growth ranges is from fourth quarter to fourth quarter. ${ }^{2}$

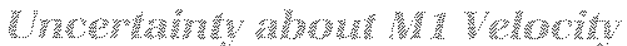

The evidence reviewed by the Committee at its February $12-13,1985$, meeting suggested that the velocity of $\mathrm{M} 1$ - the ratio of nominal GNP to M1 -

2The use of fourth-quarter-to-fourth-quarter growth targets eliminates intra-year base drit, that is, the drift of the base level from which policy growth objectives are calculated. The FOMC's use of the preceding year's actual fourth quarter levels instead of the implied level from the target range, however, has imparted an upward bias to the long-run money growth figures. For more on this point, see Broaddus and Goodfriend (1984). 
Table 1

FOMC Long-Run Operating Ranges in 1985

\begin{tabular}{|c|c|c|c|c|}
\hline \multirow[b]{2}{*}{ Date of meeting } & \multirow[b]{2}{*}{ Target period } & \multicolumn{3}{|c|}{ Ranges } \\
\hline & & M1 & $\mathbf{M 2}$ & M3 \\
\hline February $12-13,1985$ & N/1984-IV/1985 & $4-7 \%$ & $6-9 \%$ & $6-9.5 \%$ \\
\hline July $9-10,1985^{2}$. & IV/1984-IV/1985 & - & $\begin{array}{l}\text { reaffirmed } \\
\text { above range }\end{array}$ & $\begin{array}{l}\text { reaffirmed } \\
\text { above tange }\end{array}$ \\
\hline & I/1985-iV/1985 & $3-8 \%$ & $\therefore$ & - \\
\hline
\end{tabular}

Dissents.

Messrs. Boehne and Martin dissented because they preferred a somewhat higher upper boundary for the Mt range in order to provide enough leeway, if needed, to accommodate a satisfactory rate of economic expansion. In their view, the additional leeway was desirable because of the uncertainties surrounding the outlook for velocity, and it took account of the favorable outlook for inflation and the continuing financial strains in some sectors of the economy. Mr. Boehne also noted that M1 growth in 1984 was in the lower part of the Committee's range.

Mr Wallich dissented because he wanted to retain the ranges for the broad monetary aggregates that were tentatively adopted in July 1984. In his view those ranges provided adequate room for fostering a sustainable rate of economic expansion. They were more consistent with the Committee s long-run objective of bringing down inflation, and raising them might be misinterpreted by the matket as a weakering of policy in that regard:

Mr. Black dissented because he prefened a rebased range of $40 \mathrm{o}$ percent for M1, which he thought was nore likely to be consistent with both sustained economic expansion and progress toward price stability in particular, he was concerned that the higher 8 percent top of the rebased range adopted by the Committee might tend to prolong the process of reducing $M 1$ growth to a noninflationary rate.

"seemed to be retuming to a more normal or predictable pattern." "This evidence was tempered by the fact that, although M1 velocity was rising, its growth during the past few years, on average, had been lower than its growth over the bulk of the postwar period. ${ }^{4} A$ continuation of the slow growth in velocity, some members of the Committee argued, "would imply the need for M1 growth in the upper part of the Committee's tentative range' of 4 to 7 percent from $W / 1984$ to N/1985 (see table 1), as established at the July 1984 meeting.

The Committee noted that the behavior of M1 velocity was subject to considerable uncertainty. In its

Record (May 1985), p. 330. See opposite page for a brief discussion of velocity and its recent behavior. The behavior of $M t$ velocity (GNP/M1) during the past few years has created concern among FOMC members about M1's usefulness in the conduct of short-run policy. For a discussion of the effects of changes in $M 1$ velocity on policy, see Thomton (1983a) and Hafer (1985). For more on the concept, measurement and recent behavior of velocity, the reader is referred to Talom (1983), Hein and Veugelers (1983) and Thornton (1983b).

"For example, the average growth rate of M1 velocity from 1960 through 1981 was 3 percent. During 1984, $M 1$ velocity increased, on average, at a 4.2 percent rate. In contrast, from 1978 through 1983 , $M$ i velocity growth averaged oniy a 0.5 percent rate.

sRecord (May 1985), p. 330. report to Congress, the Committee pointed out that:

On average, the behavior of M1 velocity . . during 1984 was broadly consistent with previous cyclical patterns. Together with other evidence, this development suggests that the factors responsible for the highly tmusual velocity behavior over 1982 and early 1983 have receded. Nonetheless, a range of uncertainty inevitably remains about the trend of M1 relative to nominal GNP in light of recent deposit deregulation and other financial innovations....

In view of this continued uncertainty, the Committee voted to retain the tentative range for M1 growth of 4 to 7 percent from IV/1984 to IV/1985. Of the three dissents from this action on the long-run ranges (see table 1), two were based on the view that the upper bound of 7 percent might not provide enough leeway for M1 growth to accommodate a satisfactory rate of economic growth should velocity growth again slow in 1985. The other dissent concemed the ranges adopted for the broader aggregates.

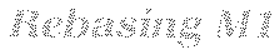

During its midyear review, the Committee discussed the rapid growth of M1 during the first six months of 1985: from December 1984 to June 1985, M1

6Report (April 1985), pp. 189-90. 


\section{Velocity, Money and Economic Activity}

The velocity of honey can be thought of as the number of theses that the noney stodk furns over to prod lece a given level of nominal heome, hi lentis of growil rales, velocity's tmpontanee is defined by Whe equation

(1) $\mathrm{M}, \mathrm{V}=\mathrm{V}=\mathrm{P}, \mathrm{X}$

where $\mathrm{M} \rightarrow$ noney stock

$$
\begin{aligned}
& \mathrm{V} \text { - velocity? } \\
& \checkmark \checkmark \text { total nominal spending. } \\
& \mathrm{P}=\text { price lovel, and } \\
& \mathrm{x} \rightleftharpoons \mathrm{real} \text { outpar }
\end{aligned}
$$

The dot above each variable indicates ihat the variables are measumed as grow h rates?

The aceompanying lable presents dath on the

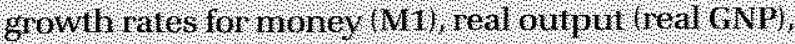
inflation (GNP deflator), nominal meone (G NP) and velocity, the data cover the most recent four years and lhe 1960 8 1 perlod?

Velocity growth duming the past four years has deviated substantialy from its average behavior over the previous wo decades. 1 rom 1960 through 1981, velocily growih averaged 3 percent. from 11982 10 1111085 , ve locity deer cased at an average rate of 16 perrent, This ehange in veloctiy growth from 1 s histonical

Velocity growth, by defin: tion, is simply the differ ence between the growth of noninal incone $(\vec{P}, x)$ and money (M) in level form, velocity is the ratio of nominal ncome 10 the money stock $(\mathrm{Y} / \mathrm{M})$.

The data for 1985 cover only the first hree quar ters, since the Commitiee had access only to hese data, and then sometimes only in prelimuary torm Moreover the revisions of the income statistics were announced in Decerbbe 1985 Also, the growth rates in the table do not precisely add up as sug gested by equation 1 The equation is based on the use of logarithmic rates of change, the growth rates in the table are compounded tates of change trend increased uncertainty about the growth of money necessary to maintain real economic expan sion. For example, in 1982, M1 increased at about a 9 percent rate Because inflation was about 5 percent and velocity anexpectedly declined by more than 5 percent, the net result was negative real economic growth' In contrast, during 1984, even though M1 growth averaged only about 5 percent, inflation was only 3.6 percent and velocity growth rebounded to a 4 percent rate; consequently, real economic growth expanded shaply.

At the beginining of 1985 , velocity was expected to retum to a more normal growth rate Instead, policymakers again were confronted with unexpectedly large sustained negative velocity growth. Conbined with relatively stable inflation, this shap, unexpected dechine in velocity yielded slow real growth, even with quite rapid growth in $\mathrm{M} 1$. The text discusses how this situation affected the fOMC during 1985 .

\begin{tabular}{|c|c|c|c|c|c|}
\hline Period & Mi & RGNP & $P$ & GNP & y \\
\hline $1960-1981$ & $53 \%$ & $3,1 \%$ & $5.2 \%$ & $8.4 \%$ & $30 \%$ \\
\hline $1 / 1982$ & 92 & ? 47 & 46 & 03 & 286 \\
\hline 114 & 30 & 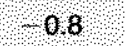 & 56 & 47 & 47 \\
\hline II & 61 & 409 & 34 & 25 & 3,4 \\
\hline v & 174 & 0.5 & 34 & 39 & 4115 \\
\hline Average & $8,9 \%$ & $+15 \%$ & $42 \%$ & $27 \%$ & $5,4 \%$ \\
\hline 11983 & 118 & 33 & 50 & 85 & 30 \\
\hline $1+?$ & 127 & 9.4 & 26 & 123 & 104 \\
\hline 11 & 10.6 & 68 & 31 & 101 & +20 \\
\hline $\mathrm{N}$ & 6.5 & 59 & 4.4 & 106 & 3.4 \\
\hline Average & $10.4 \%$ & $6.4 \%$ & $38 \%$ & $104 \%$ & $00 \%$ \\
\hline $1 / 1984$ & 6,4 & 10,1 & 44 & 149 & 80 \\
\hline मःे & 67 & 11 & 3.3 & 107 & 38 \\
\hline II & 46 & 16 & 40 & 5.6 & 10 \\
\hline $\mathrm{N}$ & 32 & 42 & 28 & 11 & 38 \\
\hline Average & $5.2 \%$ & $58 \%$ & $36 \%$ & $9.6 \%$ & $42 \%$ \\
\hline 11985 & 110 & 03 & 54 & 56 & 48 \\
\hline 1 & 10.6 & 19 & 26 & 4.5 & -55 \\
\hline 111 & 159 & 43 & 2,3 & 67 & 80 \\
\hline Average & $125 \%$ & $22 \%$ & $34 \%$ & $56 \%$ & $6,1 \%$ \\
\hline
\end{tabular}

If veloctly had ncreased at is postwar average. real output grow th would have been aboul 8 percent.

\section{Growth Rates of Velocity, Money and Economic Activity}


had increased at a 12.1 percent annual rate. Despite this rapid increase in money, however, economic growth waned from its IV/1984 pace: real GNP increased at only a 1.1 percent rate during the first hatf of 1985?

Changes in the responsiveness of the public's demand for M1 balances to changes in interest rates (its interest elasticity) were discussed as a primary expla nation for the rapid increase in M1 growth:

In periods characterized by large interest rate declines individuats and businesses tended to shift into transaction-type balances lrom other assets because they sacrificed less interest income in doing so."

Although interest rate movements in late 1984 were viewed as a likely explanation for rapid $\mathrm{M} 1$ growth early in 1985, the continuing rapid growth of M1 during May and June -.. 14.9 percent and 21.7 percent was judged to be a response by the public to more than just interest rate movements. Some members suggested that the surge was due to special, noninterest - ate factors influencing the demand for $M 1 .{ }^{\text {" }}$

The Committee did not unanimously agree on the causes of the rapid rise in $\mathrm{M} 1$ during the first half of 1985, but it "generally concluded that faster-thantargeted expansion in M1 could be accepted for the first half of the year," given the slow pace of economic activity, low inflation rate and high value of the dollar, ${ }^{\text {sa }}$ For the remainder of 1985 , the Committee deemed it undesirable to slow M1 growth enough to attain its 1985 annual target range, since this action would be detrimental to economic growth.

Instead, given the uncertainty sumounding the behavior of M1 during the first half of 1985, the Committee voted at its July meeting to rebase the M1 growth target range (see table 1):

In reexamining its $M 7$ range for 1985 and in setting a tentative range for 1986, the Committee expected that velocity, after its sharp decline in the first half of this year, would cease falling rapidly - while recognizing that much of the recent decline may not be reversed. Allowance also needed to be made for the high degree of uncertainty surrounding the behavior of M1 velocity, given the experience of the past few years. To take

${ }^{7}$ Because inflation had continued at a moderate pace, much of the decline in real GNP growth can be explained by a slowing in nominal income growth (see page 7).

Record (October 1985), p. 783.

Among the special factors discussed were changes in corporate cash management practices and transitory responses to sharp declines in Treasury balances.

${ }^{70}$ Record (October 1985), p. 783 account of these considerations, the base for the range of Ml was shifted forward to the second quarter of 1985 , and the range was set to encompass growth at an annual rate of 3 to 8 percent over the second half of this year."

At the time of the July meeting, the level of M1 alfeady was above the new annual growth range. The Committee, recognizing this fact, admitted that "it IM1 was not likely to fall within that range until some time had elapsed." " The growth of M1 would continue to be judged in light of developments in economic activity, prices, financial market changes and international developments.

\section{美, w}

Most members agreed that, in setting the 1985 growth range for $\mathrm{M} 2$ and $\mathrm{M} 3$, the upper bound of both ranges should be increased by $1 / 2$ percentage point over the tentative ranges established in July 1984. Thus, at the Febuary 1985 meeting, the Committee set the 1985 target range at 6 to 9 percent for $\mathrm{M} 2$ and at 6 to 9.5 percent for M3 (see table 1 ) " Some members ar" gued that the increase in the M3 range was unnecessary, partly because the increased ranges might impart the (incorrect) notion that the Committee's resolve to fight inflation was waning.

The Committee reaffimed the 1985 target ranges for the broader aggregates at its July meeting (see table 1). At this time, the actual growth rate for M2 was near the upper bound of its 1985 range, and M3 was somewhat above the midpoint of its range.

\section{W}

The actual and expected growth rates of the monetary aggregates for 1985 are reported in table 2 . For M2 and M3, the target period is from IV/1984 to IV/1985, while for M1 it is from I/1985 to IV/1985. The actual growth of M1, 12.4 percent, was over four percentage points above the upper bound of the Committee's 3 to 8 percent target range. In addition, M1 growth of 11.6 percent from IV/1984 to IV/1985 was more than double its 1984 growth rate of 5.2 percent.

The growth rates of $\mathrm{M} 2$ and $\mathrm{M} 3$ were within the Committee's target tanges for the year. The 8.6 percent

\footnotetext{
1 Heport (September 1985), pp. 672-73.

12Record (October 1985), p. 784.

3 The monitoring range for total domestic nonfinancial debt was set at 9 to 12 percent, 1 percentage point above its previous tentative mortitoring rafige.
} 
Table 2

\section{Actual and Expected Money Growth in} 1985

\begin{tabular}{|c|c|c|}
\hline Measure & Target Range & Actual \\
\hline$M$ & $3-8 \%$ & $124 \%$ \\
\hline $\mathrm{M} 2$ & $6-9$ & 86 \\
\hline M3 & 6.95 & 80 \\
\hline
\end{tabular}

NOTE The target period to M/ Is W1985 to W/1985, The target period for M2 and M3 is W/1984 Lo W/ 985.

growth rate of M2 was near the upper end of its growth range, while M3's 8.0 percent growth rate was 1.5 percentage points below its upper bound. In both instances, the growth rates for the broader aggregates were only slightly above their 1984 rates of 7.7 percent and 10.4 percent, respectively.

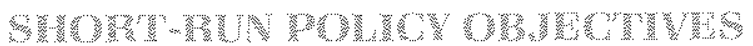

The Committee met eight fimes during 1985 to review the state of the economy and determine shortFun changes in monetary policy implementation. The following is a chronological discussion of these shortrun decisions.

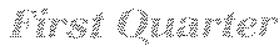

The economic data reviewed at the February meet ing showed that real economic growth had been strengthening in late 1984. 'The Commerce Department's preliminary estimate of real GNP growth in IV/1984 was about 4 percent, up from about 1.5 percent in 11/1984. Industrial production also showed strength after declining in September and October.

Though the monetary aggregates were growing well above the short-term targets established at the December 17-18, 1984, meeting (see table 3), members were reluctant to initiate policy actions that would reduce the availability of reserves to the banking system.

The Committee's reluctance to reduce money growth stemmed from the continued uncertainty about the sustainability of the recent increase in economic growth. Some members argued for policy actions that would lead to slower money growth; others felt that the pace of economic growth during late 1984 reflected the public's reaction to rapid de- clines in interest rates. ${ }^{\text {id }}$ Also concemed about the effects of the federal government's budget deficit and the growing foreign trade deficit on domestic economic growth, the Committee cautioned against slowing money growth merely to achieve pre-stated growth ranges: "relatively rapid monetary growth would not automatically call for more reserve restraint if it occurred in the context of emerging weakness in business conditions and a strong dollar in the foretgn exchange markets." Most Committee members at the February meeting thought that its actions were consistent with achieving the monetary growth rates for the first quarter shown in table 3.

At the March 26 meeting, incoming economic data indicated an econorny growing more slowly than in IV/1984. Partial data for March also showed a sharp slowing in the growth of the monetary aggregates. The Committee agreed that the current economic outlook outweighed any move to restrain monetary growth further. Its decision to maintain the existing degree of reserve restraint, in combination with the observed slowing in money growth, led it to expect a slowing in money growth over the next few months. The Committee cautioned, however,

... that the current economic uncertainties and related volatility that appeared to pervade domestic credit and foreign exchange markets would argue for more tolerance toward growth in the aggregates, particularly to the extent that such growth might signify an increase in demands for liquidity."

In other words, if (for whatever reason) the public's demand for money should again increase substantially (that is, if velocity should fall, the Committee would lean toward accommodating such demands by increasing the supply of reserves.

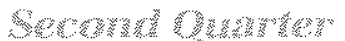

After the growth of $\mathrm{M} 1$ remained above its annual target through April, two conflicting views among Committee members emerged at the May 21 meeting. One view argued for holding near-term $M 1$ growth to a rate that would bring it closer to its annual target, lest the above-target growth have an undesirable impact on inflationary expectations.

\footnotetext{
"Using monthly averages, the rate on three-month Treasury bills fell 273 basis points between August 1984 and January 1985 . Over this period, the 30-day commercial paper rate fell 320 basis points. Long-term rates also fell appreciably: 76 basis points for long-term government securities and 79 basis points for Aaa corporate bonds.

${ }^{15}$ Record (May 1985), p. 332.

${ }_{16}^{16}$ Record (July 1985), pp. 539-40.
} 
Table 3

\section{FOMC Short-Run Operating Specifications}

\begin{tabular}{|c|c|c|c|c|c|}
\hline \multirow[b]{2}{*}{ Meeting date } & \multirow[b]{2}{*}{ Target period } & \multicolumn{3}{|c|}{ Expected growth rates } & \multirow{2}{*}{$\begin{array}{l}\text { Intermeeting } \\
\text { federal funds } \\
\text { range }\end{array}$} \\
\hline & & M1 & M2 & M3 & \\
\hline December $17-18,1984$ & November 1984 March 1985 & around $7 \%$ & around $9 \%$ & around $9 \%$ & $6-10 \%$ \\
\hline Februafy $12-13,1985$ & Decernber 1984 March 1985 & around 8 & around 10-1t & around $10-11$ & $6-10$ \\
\hline March 26,1985 & March June 1985 & around 6 & around 7 & around 8 & $6-10$ \\
\hline May 21, $1985^{2}$ & March-June 1985 & $\begin{array}{l}\text { around } 6 \\
\text { or a little } \\
\text { higher }\end{array}$ & less than 7 & less than 8 & $6-10$ \\
\hline July $9-10,1985^{3}$ & June September 1985 & 5 to 6 & around 7.5 & around 7.5 & $6-10$ \\
\hline August $20,1985^{4}$ & June September 1985 & 8 to 9 & around 8.5 & around 6.5 & $6-10$ \\
\hline October $1,1985^{\circ}$ & September December 1985 & around $6-7$ & about $6-7$ & about $6-7$ & $6-10$ \\
\hline November 45,1985 & September-December 1985 & around 6 & about 6 & about 6 & $6-10$ \\
\hline December $16-17,19857$ & November 1985 March 1986 & 7109 & about $6-8$ & about $6-8$ & $6-10$ \\
\hline
\end{tabular}

Mr. Solomon dissented from this action because, although he thought some further easing would be appropriate over the coming period, he believed such action should be relatively gradual, in particular, he was concerned that the provision of reserves sotight by the Committee fisked an excessive dedine in short-term rates and an overreaction in the financial markets. He therefore preferred a more cautious probing toward easier reserve conditions.

Mr Gramley dissented because he could not accept a directive that called for further easing of reserve conditions. In his view the underlying strength of the economy together with the ongoing etfects of earlier dectines in interest rates provided the basis for a likely rebound in economic growth duning 1985 . He also believed that the Commitee needed to take greater account of the broader monetary aggregates whose expansion appeared to be exceeding the Committee's expectations by a substantial margin in the fourth quarter. Under current circumstances he was concerned that significant further easing of reserve conditions would foster additional declines in interest rates that would have to be reversed later as economic growth picked up again.

Mr. Black dissented because he preferted to direct policy implementation in the weeks immediately ahead toward achieving somewhat slower expansion in M1. In his view, bringing M1 growth more promptly within the Committee's range for the year would help guard against a possible worsening of inflationary expectations and would limit the risk of a potentially unselting movement in interest rates later in the year.

${ }^{3}$ Mr. Black dissented because he believed some increase in the degree of reserve pressure was needed to help assure an adequate stowing of M1 growth over the months ahead. Ms. Seger dissented because she favored some easing of reserve conditions to help reduce current financial strains, moderate the strength of the dollar in foreign exchange markets $s_{*}$ and promote faster economic expansion.

${ }^{4} \mathrm{Mr}$. Black dissented because he preferred to direct open market operations promptly toward a somewhat greater degree of reserve restraint and thereby improve the prospects of moderating M1 growth to within the Committee's range for the second half of the year. Ms. Seger dissented because she favored some reduction in the degree of reserve restraint in light of the financial vulnerability of some sectors of the economy and in order to encourage sustained economic expansion.

5Mr. Black dissented because he believed some increase in the degree of reserve pressure was needed at this time to ensure adequate slowing of M1 growth in the period ahead.

${ }^{6} \mathrm{Ms}$. Seger dissented because she believed that some reduction in the degree of reserve restraint was needed to help relieve financial strains in the economy, and to promote a more acceptable fate of economic expansion closer to the faster growth expected by Committee members early this year.

'Mr. Black dissented because he was concerned about the rapid growth of M1 and he did not think a decrease in the degree of pressure on reserve positions was desirable under present circumstances.

The other view focused on the current sluggishness of economic activity: "A number of members indicated that they were prepared to accept a little more rapid expansion [of $\mathrm{M} 1$ ] against the background of relatively weak economic performance, strains in financial markets, and the recent behavior of the broader aggregates." Preliminary data suggested that second-

17Record (September 1985), p. 711. Il also should be noted that preliminary data indicated a substantial drop in Mr velocity. quarter real GNP would increase only modestly following its lackluster 0.7 percent growth in $\mathrm{V} / 1985$. Moreover, the "recent decline in market rates and the lower discount rate would tend to increase the dem mands for money and credit under those circumstances as compared with what they otherwise would be." In other words, faster money growth would be

${ }_{18}$ tbid. The discount rate was lowered from 8.0 percent to 7.5 percent on May 20, 1985 


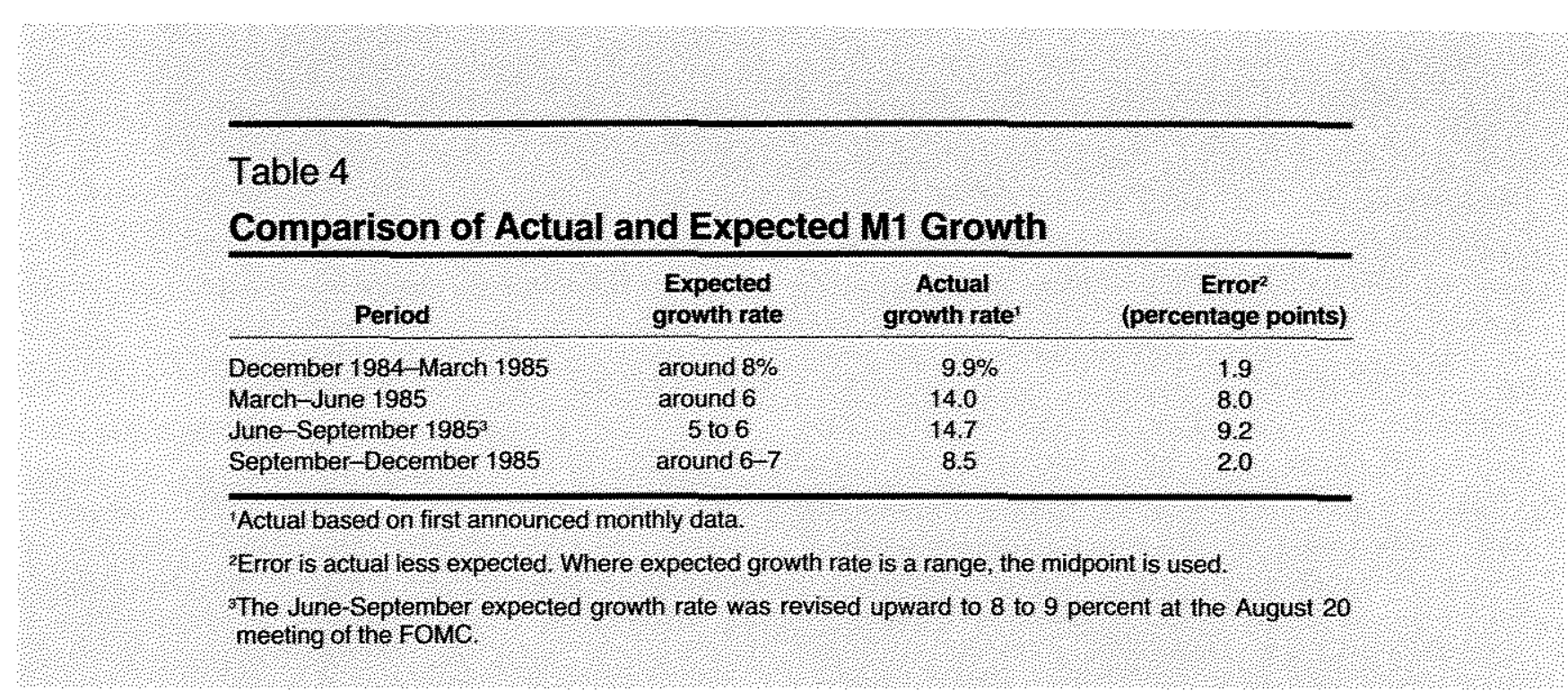

necessary to accommodate desired GNP growth.

The Committee's discussion at the May 21 meeting indicates that it viewed the short-run behavior of the money supply as being influenced by the course of the public's demand for money. ${ }^{13}$ Because the economy remained sluggish and interest rate declines had abated, the demand for $\mathrm{M} 1$ and, consequently, its growth were expected to slow. Given the strength of M1 relative to its annual target, most members were willing to accept slightly less growth in the broader M2 and M3 aggregates.

Contrary to the Committee's expectations, M1 growth surged in May and June, increasing at rates of about 15 percent and 22 percent. As shown in table 4 , M1 growth over the March-June period was 14 percent, more than double the rate expected. The growth rates of $\mathrm{M} 2$ and $\mathrm{M3}$, however, were more consistent with the Committee's expectations: over the same period, $\mathrm{M} 2$ and $\mathrm{M} 3$ increased at rates of 7.4 percent and 6.5 percent.

\section{Whis}

We have seen that the Committee voted at its July meeting to rebase the $\mathrm{M} 1$ growth range on the heels of unexpectedly rapid M1 growth in May and June. Although some members argued that such rapid growth

\footnotetext{
${ }^{19}$ Axilrod (1985), p. 22, provides a basis for this viewpoint. He notes that:

It does not necessarily tolfow that a money supply target, or guide. shout be abandoned when there are shifts in the demand for money. So tong as shitts in demand for goods and services are with us. . . thefe is obvious value to a money supply guide, but one that necessarily entais certain judgmental adjustments to alfow for, among other things. shifts in money demand.
}

required a tightening of reserve availability to slow future M1 growth and bring it into the new target range, a "majority of the members were in favor ... [of] maintaining the existing degree of pressure on reserve positions ..." which was "likely to be associated with a marked slowing in the growth of M1 during the third quarter." "The Committee expected that the unanticipated surge in non-interest-bearing demand deposits during the second quarter "would appear to have satisfied transactions needs for some period ahead."2s

By the August 20 meeting, the question of how the recent strength of $\mathrm{M} 1$ growth relative to sluggish economic activity would affect policy implementation for the upcoming weeks assumed center stage. Although M1 growth had been exceptionally strong during the first half of 1985, and inflation continued at a moderate pace, economic activity showed no appreciable rebound as velocity continued to decline. Meanwhile, the trade-weighted value of the dollar against major foreign curmencies had fallen about 17 percent from its peak value in late February.

The absence of any clear indication that economic activity was strengthening led some members to argue that maintaining the existing degree of reserve restraint would result in a moderation of future M1 growth. More important, since recent data showed no significant acceleration in either economic activity or

\footnotetext{
${ }^{20}$ Record (October 1985), p. 786.

${ }^{2}$ lbid. The unusual surge in demand deposits during May and June was greater than interest rate declines would have predicted. Two possible explanations were advanced in the Report: shafp swings in U.S. Treasury balances and possible changes in corporate cast management techniques.
} 


\section{Organization of the Committee in 1985}

The Federal Open Market Committee (FoMC consists of 12 members the seven nembers of the Federal Resenve Board of Governors and five of the 12 Federal Reserve Bank presidents. The chatrman of the Board of Govemors is, by tradition, also chaiman of the Committee. The president of the New York Federal Reserve Bank also by tradition is its vice chamrman all Federal Reserve Bank presidents attend Committee meetings and present their views, but only those presidents who are members of the Committee may vote. Four memberships rotate among bank presidents and are held for one year terms beginning March 1 of each year. The president of the New York Federal Re serve Bank is a permanent voting nember of the Committee.

Members of the Board of Govemors at the beginning of 1985 included Chaiman Paul A volcker, Preston Martin Henry C Walleh I Charles Partee, Emmett I. Rice, Lyle E Gramley and Martha R. Seger Effective September 1, Lyle E, Gramley resigned his governorship, a position that was not filled for the remainder of the year' The following presidents voted at the rebruary 1985 meeting: John J Balles (San Francisco), Edward G Boehne (Philadelphia), Robert H, Boykin (Dallas), E. Gerald Corrigan (New York) and Karen N Horn (Cleve(and) The Committee membership changed in March 1985 and the presidents voting positions were filled by John J Balles (San Francisco), Robert P. Black (Richmond/ ${ }_{s}$ E Gerald Corrigan (New York), Robent P Forrestal (Atlanta) and silas Keehn (Chicago).

The committee met eight times at regularly scheduled meetings during 1985 to discuss, among other things, economic trends and to deeide upon the future course of open market operations ${ }^{3} \mathrm{As}$ in previous years, however telephone or telegram consultations were held occasionally between scheduled meetings. During each regularly scheduled meeting, a directive was issued to the Federal Reserve Bank of New York Each directive con-

Gramey did not attend the July and August meeting.

Balles voted as an alternate at this meeting.

No formal meetings were held in January, Aprif, June and September. taned a short review of economic developments, the general economic goals sought by the Committee, the Committee's long-run monetary growth objectives, and instructions to the manager of the System Open Market Account at the New York Bank for the conduct of open market operations. These instructions typically were stated in terms of the reserve conditions deened consistent with the short term growth rates for M1, M2 and M3, which in tum were considered to be consistent with desired longer-run growth rates of the monetary aggregates. The Committee also specified intermeeting ranges for the federal funds rate, These ranges provide a mechanism for initiating consul tations between meetings whenever it appears that the constraint of the federal funds rate is proving inconsistent with the objectives for the behavior of the monetary aggregates.

The aceount manager has the major responsibility for formulating plans regarding the timing, types and amount of daily buying and seling of securities in fulfilling the Conmittee's directive. Each morning the manager and his staff plan the open market operations for that day. This plan is developed on the basis of the Committee's directive and the latest developments affecting money and eredit market conditions, the growth of the monetary aggregates and bank reserve conditions. The manager also consults with the Board of Gov: ennors staff Present market conditions and open market operations that the manager proposes to execute are discussed each morning in a telephone conference call involving the staff at the New York Bank and the Board and one voting president. Other members of the Committee may participate and are informed of the daily plan by internal memo or wire.

The directives issued by the committee and a summary of the reasons for Committee actions are published in the trecord of Policy Actions of the Federal Open Market Committee" The "Record" for each meeting is released a few days after the following Committee meeting Soon after its release, it appears in the Federal Reserve Bulletin in addition, "Reconds" for the entire year are published in the annual report of the Board of Governors The "Record" for each meeting during 1985 included: 
11 a staff summay of reeent economic develop

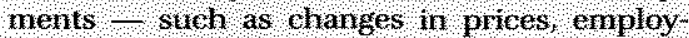
ment, industrial production and components of the national income aceounts and propections of general price, output and enploynent devel opments for the year ahead;

2 a summary of recent international financial developments and the $U$ s foreign trade balance,

3 a summary of open nanket operations, growth of the monetary aggregates and bank reserves, and money market conditions since the previous neeting -

4 a summary of the Committees discussion of the ctment and prospective econonict and financial

inflation, the Committee argued that a rigid adherence to the long-run Mi growth objectives entailed a greater downside risk to the expansion than the risk of greater inflation.

The Committee voted at the August meeting to "maintain the degree of pressure on reserve positions sought in recent weeks." It viewed this action as consistent with M1 growth of 8 to 9 percent for IIV 1985, a substantial increase from the short-term growth range expected at the July meeting (see table 3). M2 growth was expected to increase somewhat, while M3 growth was expected to fall slightly. The Committee's policy directive noted, however, that "somewhat greater restraint would be acceptable in the event of substantially higher growth in the monetary aggregates." 3 In fact, open market operations during the intermeeting period following the August vote showed a slight tilt toward reserve restraint.

As table 4 reveals, the Committee substantially underestimated M1 growth for III/1985. Nevertheless, the pace of economic activity, the inflation rate, movements in the foreign exchange value of the dollar and the growth of the broader monetary aggregates argued against the need to further restrict reserve availability in order to bring $\mathrm{M} 1$ growth into its target range.

\section{Wortary}

At the October meeting, evidence indicated that the economy was beginning to expand at a faster rate than

\footnotetext{
2aRecord (December 1985), p. 954.

zaibid.
}

conditions and the anent poliey consider ations, including noney narket conditions and the novement of nonetary aggregates;

5 decisions of the Committee,

6) a policy directive is sued by the Commintee to the Federal Resene Bank of New York,

7 a list of the members votes and any dissenting comments, and

$8)$ a deseription of any attions regarding the committee s other atthomations and directrves and any actions or constlations that may have oc. curred between the regularly scheduled meetings.

in the first half of 1985 and that inflation pressures continued to be weak. Following the September 22 announcement by finance ministers and central bank governors of the Group of Five (G-5) countries, the foreign exchange value of the dollar had started to decline again after some increase in early September. ${ }^{24}$

Recent data suggested that M1 growth might decline in the upcoming weeks. (Indeed, M1 growth did drop from 22.4 percent in August to 12.4 percent in September.) An analysis prepared by the Board staff indicated that "given the volatility of the M1 data and the difficulties of making seasonal adjustments, a decline in M1 for a time could not be ruled out," "sven so, the analysis suggested that M1 growth during IV/1985 probably would continue strong unless market interest rates rose substantially from current levels and that it was "increasingly doubtful that the targeted rate of $\mathrm{M1}$ growth for the second half of the year as a whole could be reached without an inappropriately abrupt increase in reserve pressures and in interest rates."

With continued uncertainty surrounding the future behavior of $M 1$ velocity, the Committee voted to maintain the policy stance established in recent weeks.

\footnotetext{
24The G-5 countries include France, Germany, Japan, the United Kingdom and the United States. For a discussion of the announcement and its immediate impact, see Trehan (1985). See also Axilrod (1986) for a related discussion.

isRecord (January 1986), p. 23.

26ibid. The "inappropriateness" of tightening policy reflects the Committee's continued concern over the sluggish behavior of real GNP relative to observed monetary growih.
} 
This action, as table 3 shows, was deemed consistent with a slowing in M1 growth from IIV/1985 to IV/1985. This policy also was expected to produce SeptemberDecember growth rates for M2 and M3 of about 6 to 7 percent.

Data available at the November $4-5$ meeting showed economic growth to be slowing from its third-quarter rate and inflation continuing at a moderate rate. The dollar exchange rate against major currencies had declined about 1.5 percent more since the October 1 meeting

Board staff projections discussed at this meeting pointed to modest real economic growth and low inflation both for the fourth quarter and throughout 1986. Some Committee members continued to express concem that the unevenness of economic growth among different sectors could increase the risk of slowing down the pace of expansion. Concern over uneven growth was heightened by the possible effects of pending legislation to reduce the federal budget deficit and the behavior of the dollar in foreign exchange markets.

The exchange value of the dollar's effect on foreign trade and certain sectors of the economy had be come an important policy consideration following the G-5 meeting in September. A decline in the value of the dollar relative to other currencies would have a favorable impact on some domestic industries. A precipitous decline in the value of the dollar, however, would be unsettling and undesirable. Because of the uncertainties that remained about M1 velocity and future economic activity (M1 velocity continued to fall in $11 / 1985$ as it had in the previous two quarters), a reserve tightening campaign to push M1 within its annual target by year's end was judged unwise. ${ }^{27}$ Instead, the Committee favored no change in reserve availability for the intermeeting period. The behavior of M1 would continue to be viewed in the broader context of the prevailing economic conditions, with acceptance of above-target growth for the second half of 1985 .

As shown in table 3 , this policy was expected to produce $M 1$ growth of around 6 percent, and $M 2$ and M3 growth rates of about 6 percent, for the September-December period. A slowdown in M1 growth for the fourth quarter was expected, in part, because M1 had declined at a -1.6 percent rate in October. By

\footnotetext{
${ }^{27} \mathrm{M} 1$ velocity declined at an 8 percent rate in $\neq 1 \mathrm{l} / 1985$. The rates of decline in $1 / 1985$ and $1 / 1985$ were -4.8 and -5.5 percent.
}

following a policy of maintaining the "current degree of reserve restraint," the Committee argued, "the expansion of M1 was expected to slow considerably in the fourth quarter to a rate much closer to that of nominal GNP." 23

At its December meeting, uncertainty over the proper course of policy continued to prevail. The growth of M1 had surged in November, increasing at about a 13 percent rate, compared with the 1.6 rate of decrease for October. M2 and M3, however, increased at moderate rates in November.

The importance of this disparate growth in M1 relative to the broader monefary aggregates and the continuing declines in M1 velocity emerged as the Committee increasingly relied on economic conditions as a guide to establishing intermeeting policy directives. Economic data available at the December meeting continued to reveal a slowly growing econ* omy that evidently was not responding to the rapid money growth of previous quarters. A majority of members consequently argued for "moving' toward implementing some slight easing of reserve conditions," noting that "decisions about the precise degree of reserve pressure should depend in part on whether the discount rate was reduced, and if so by how much." 29

Although some members expressed concem that continued rapid money growth might ignite inflationary expectations, most "saw little reason at this time to expect significant changes from the rates of increase experienced in 1985." "More important to the policy decision at this meeting was the concern that the rate of economic growth in 1986 might be inadequate, implying that velocity would remain well below its post-war growth rate. Some Committee members viewed easing of reserve availability as a means to foster lower long-term interest rates further, "which would help sustain the economy" and lessen "the financial strains in some sectors of the economy and the external debt problems of several developing countries.".s.

The Committee's directive following this meeting called for "some limited decrease in the degree of pressure on reserve positions,"s This directive was

\footnotetext{
2aecord (February 1986), p. 131

${ }^{2}$ Record (Aprif 1986), p. 249.

solbid.

"thid.

${ }^{32}$ Record (Aprit 1986), p. 250
} 
clarified by the observation that "most [members] believed that policy implementation should be especially alert to the potential need for some further easing in light of the relatively sluggish performance of the economy and the generally favorable outlook for prices and wages." nomic developments would set the fone for policy actions in the near future.

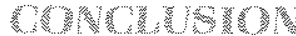

Numerous crosscurrents influenced the FOMC's decisions during 1985. The economy expanded at a relatively slow pace and prices increased at rates reminiscent of pre-OPEC times. The foreign trade imbalance worsened throughout 1985 , though the falling dollar prompted hope for some relief in the future. Falling commodity prices, especially oil puces, raised fears about the ability of debtor nations to repay outstanding loans including those to U.S. commercial banks.

The sharp fall in M1's income velocity continued to influence long-term policy actions and short-term policy implementation. As had happened several years earlier, the demand for money began to deviate markedly from forecasts, Consequently, monetary policy sought to accommodate increasing demands for money, resulting in rapid M1 growth. A major question facing monetary policy for 1986 is whether veloc

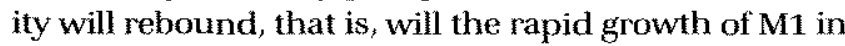
1985 assert itself in more rapid income growth and inflation during 1986 ?

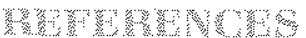

Axilrod, Stephen. "U,S. Monetary Policy in Recent Years: An Over view," Federal Reserve Bulletin (January 1985), pp. 14-24.

"Statement before the Subcommittee on Domestic Monetary Policy," Federal Reserve Bulletin (January 1986), pp. $15-17$

Broaddus, Alfred, and Marvin Goodfriend. "Base Drift and the Longer-Run Growth of M1: Experience from a Decade of Monetary Targeting," Federal Reserve Bank of Aichmond Economic Review (November/December 1984), pp. 3-14.

Federal Reserve Bank of San Francisco. Monetary Targeting and Velocity: Conference Proceedings (1983).

Hafer, R. W. "The FOMC in 1983-84: Setting Policy in an Uncertain World," this Review (April 1985), pp. 15-37.

Hein, Scott E., and Paul T. W. M. Veugeters. "Predicting Velocity Growth: A Time Series Perspective, "this Review (October 1983), pp. $34-43$

${ }^{3}$ ibid.
Tatom, John A. "Was the 1982 Velocity Dectine Unusual?" this Review (August/September 1983), pp. 5-15.

Thornton, Daniel L. "The FOMC in 1982: De-emphasizing M1," this Review (June/July 1983a), pp. 26-35.

"Why Does Velocity Matter?" this Review (December 1983b), pp. 5-13.

Trehan, Bharat. "The September G-5 Meeting and its Impact," Federal Reserve Bank of San Francisco Weekly Letter (December 13, 1985).

\section{Supplement \\ FOMC Discussions in 1985}

\begin{abstract}
HIS supplement provides a chronological account of policy discussions of the FOMC in 1985. The selected excerpts are taken from the "Record of Policy Actions," the full text of which is published in the Federal Reserve Bullerin and the Board's Annual Report. Included in each "Record" are analyses of current economic conditions, staff projec" tions of future economic developments, discussion of existing and possible policy actions and a reporting of the operating instructions issued by the FOMC.
\end{abstract}

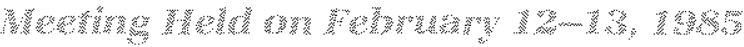

The information reviewed at this meeting suggested that the rate of economic expansion strengthened in late 1984. For the fourth quarter as a whole, growth in real gross national product picked up to an annual rate of about 4 percent, according to the preliminary estimate of the Com merce Department, from about 1-1/2 percent in the third quatter, and there was evidence of continued moderate expansion in early 1985. . Broad measures of prices and wages generally continued to rise in 1984 at rates close to those recorded in 1983.

After growing little on balance since early summer, M1 expanded at estimated annual rates of about 10-1/2 and 9 percent respectively in December and January. M2 and M3 also expanded rapidly over the two months, rising on average at annual rates estimated to be around 14 and $13-1 / 2$ percent respectively, considerably above the short-run objectives for the November-to-March period established at the December meeting. Relative to the Committee's longerrun objectives for the period from the fourth quarter of 1983 to the fourth quarter of 1984, M1 grew at a rate of about 5-1/4 percent. somewhat below the midpoint of its 4 to 8 percent range, and $M 2$ increased at a tate of about $7-3 / 4$ percent, a bit above the midpoint of its 6 to 9 percent range. M3 and domestic nonfinancial sector debt expanded at rates of about 10-1/2 and 13-1/2 percent respectively, above the Committee's ranges of 6 to 9 percent and 8 to 11 percent for the year. 
In the first part of the recent intermeeting interval, open market operations were directed toward achieving some further reduction in pressures on reserve positions. Adjust"ment plus seasonal borrowing at the discount window, after bulging around year-end, declined to the $\$ 250$ million to $\$ 300$ million range over much of January. By the latter part of January, against the background of continued apid growth in the monetary and credit aggregates and the relatively good performance of the economy, the easing process came to an end; reserves were provided more cautiously through open market operations, and borrowing rose somewhat, partly because of unexpectedly large demands for excess reserves.

In the Committee's discussion of the economic situation and outlook the members agreed that continuing expansion in business activity was a likely prospect for 1985 . though at a more moderate rate than in the first two years of the current cyclical upswing.

While a number of members commented during the discussion that actual growth in line with the forecasts would represent a favorable development for the third year of an economic expansion, several observed that growth might well be faster, especially in the short run. This possibility was raised by current indications of appreciable strength in both consumer and business spending and an expansive fiscal policy. It was also pointed out that a large decline in the foreign exchange value of the dollar, should it occur, would tend to stimulate domestic business activity while also adding to inflationary pressures.

In the course of their discussion, the members referred to evidence that the income velocity of M1 - nominal GNP divided by the M1 stock -.-meemed to be returning to a more normal or predictable pattern. Some analysis suggested that the trend growth of M1 velocity might be somewhat lower than that experienced over much of the postwar period, reflecting in part the deregulation of deposits and other financial changes in recent years and the related prospect of a slower rate of financial innovation in the future. A number of members emphasized that such a development would imply the need for M1 growth in the upper part of the Committee's tentative range. It was also noted that the lagged effects of the interest rate declines during the latter part of 1984 were likely to depress velocity growth in the first part of 1985 . Other members raised the prospect that the growth in M1 velocity might not decline as much as expected from the rate experienced in 1984 and in that event growth of $\mathrm{M} 1$ near the upper limit of the tentative range, or above it, would have inflationary implications. The members agreed that the trend rate of increase in M1 velocity, as well as the velocity of the other monetary aggregates, remained subject to a considerable range of uncertainty, given the still limited experience with a felatively deregulated financial environment. Inder these conditions, the Committee members indicated the need to con tinue to judge the behavior of the monetary aggregates in light of the flow of information on business activity, in- flationary pressures, and conditions in domestic credit and foreign exchange makets.

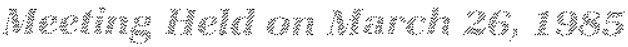

Growth in M1 accelerated to an annual rate of about 14 percent in February from 9 percent in January, but partial data available for March indicated a considerable slowing. Growth in M2 and M3 moderated somewhat in February and averaged about 12 percent and 9 percent respectively over the January-Februaly period. As with $\mathrm{M} 1$, growth in the broader aggregates appeared to be slowing considerably in Maech.

[However] considerable concern was expressed about the sensitive conditions in domestic financial and foreign exchange markets, especially against the background of the distortions and uncertainties stemming from massive and persisting deficits in the federal budget and the record and still widening gap in the nation's balance of trade. The members referred to the quite different trends in various sectors of the economy; in general, the service industries were doing well while industries related to agriculture, mining, energy, and a number of manufacturing activities were experiencing a variety of problems and were subject to varying degrees of financial strain.

The prospective performance of business fixed investment was cited as a key element in the outlook for economic activity. While the members generally anticipated further expansion in investment spending, developments over the course of recent months together with the results of surveys of business intentions suggested a pronounced deceleration from the unusually rapid growth experienced during the first two years of the current expansion.

The members recognized that current uncertainties about the economic outlook and the sensitive conditions in domestic credit and foreign exchange makets weighed against a significant increase in the degree of reserve re straint. At the same time, several placed considerable emphasis on the desirability of fostering slower monetary expansion over the period ahead to help assure growth within the Committee's target ranges for the year.

While no member contemplated the need for a substanial move toward greater reserve restraint, some commented that a small but timely move might well avert the necessity for a more vigorous, and potentially more disfuptive, adjustment later. On the other hand, a number of members felt that the current economic uncertainties and related volatility that appeared to pervade domestic credit and foreign exchange markets would argue for more tolerance toward growth in the aggregates, particularly to the extent that such growth might signify an increase in demands for liquidity.

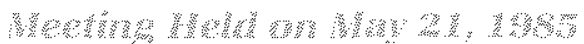

The information reviewed at this meeting suggested only a modest pickup in real GNP in the current quarter from the 
0.7 percent annual rate of growth reported for the first quarter. Spending by domestic sectors has been relatively well maintained, but a large share of the demand for goods apparently has been met by imports mather than through an expansion of domestic production. Broad measures of prices and wages generally were continuing to rise at rates close to those recorded in 1984 .

Growth in M1, which had slowed makkedly in March from the rapid pace of earlier months, remained moderate in April at an annual rate of about 6 percent. $\mathrm{M} 2$ and $\mathrm{M} 3$, after slowing appreciably in March to annual rates of growth of about $3-3 / 4$ and $5-1 / 2$ percent respectively, were little changed in April. Thus, while expansion in M1 was about in line with the Committee's expectations for the March-toJune period, growth in the broader aggregates was running well below the rates anticipated.

During their review of the economic sifuation and outlook, Committee members focused with concern on evidence that the economy, despite elements of strength, was expanding at a relatively sluggish pace; and they also stressed the uncertainties that surounded the prospects for some pickup in the rate of economic growth. The cur rently mixed pattern of developments greatly complicated the forecasting process, especially against the background of the distortions and pressures associated with massive deficits in the federal budget and the balance of trade, together with persisting strains in financial markets.

A number of members expressed particular concern about the depressing impact that the competition of foreign goods was having on domestic production, and some commented that the outlook for the dollar in the exchange markets constituted the major uncertainty in assessing economic prospects. While domestic final demands were being reasonably well maintained, a strong dollar was diverting these demands toward imports, which were growing rapidly, and holding back domestic output. The strength of the dollar was also tending to curb the expan sion of exports.

Given the reatively low rates of capacity utilization and the outlook for only limited growth in economic activity, members indicated that the rusks of an acceleration in the rate of inflation appeared to be low. Some members noted their concern, however, that current inflation rates were too high - with recent tendencies in consumer prices worrisome - especially in light of the inflationary implications of a possible decline over time in the foreign exchange value of the dollar.

In the course of discussion if was noted that M1 had been growing about as expected at the previous meeting, but that some pickup in growth could develop in the period ahead. Anumber of members indicated that they were prepared to accept a little more rapid expansion against the background of relatively weak economic perfommance, strains in financial markets, and the recent behavior of the broades aggregates. It was also pointed ou that much of the in crease in M1 thus far this year relected expansion in interest-bearing checking accounts. Banks and thrifts had reduced interest rates on these accounts only slowly in response to declines in market yields that had begun in the latter part of last year, thereby making it relatively more attractive for the public to hold savings in such instruments. Nonetheless, M1 was running above the path associated with its long-run target and some members stressed the desirability of holding down near-term M1 growth, partly because of rate of growth that appeared unduly high could risk having an adverse impact on inflationary sentiment

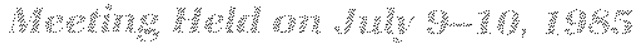

In May and June, M1 expanded very rapidly, and its growth over the March-to-June interval was at an annual rate of about $13-1 / 4$ percent, well above the rate expected at the time of the May meeting. The strength in $M 1$ was evident in all its major components, particularly in demand deposits. That strength, coupled with an acceleration in the nontransaction component of $\mathrm{M} 2$ in June, brought growth in the broader aggregates to rates somewhat higher than expected in May for the three-month period. Nevertheless, for the period from the fourth quarter of 1984 through the second quarter of $1985, \mathrm{M} 2$ and $\mathrm{M} 3$ expanded at rates within their long-tern ranges, while $M 1$ grew at a rate well above its range.

Total reserves grew rapidly in May and Jume, reflecting increases in required reserves associated with the growth in transaction accounts. The level of adjustment plus seasonal borrowing averaged around $\$ 550$ million in the three complete maintenance periods between meetings and was running over $\$ 1.2$ billion in the week before this meeting, as seasonal strains associated with the midyear statement date and the holiday period, logether with massive swings in Treasury balances, complicated reserve management at depository institutions and the Fedenal Reserve.

In support of their expectation that the rate of economic expansion would improve from the very sluggish pace experienced in the first half of the year, members referred to the favorable impact of reduced interest rates on interestsensitive sectors of the economy, such as the constuction and automobile industries, and they also noted the buildup of liquidity in the economy.

With regard to the outlook for inflation, the members noted that wage and price pressures were relatively subdued in domestic labor and product markets. Inflationary pressures were greater in some of the service inclustries, but against the background of generally low capacity utilization rates and relatively high unemployment the members did not expect much change in the overall rate of inflation during the year ahead, at least in the absence of ary sizable decline in the foreign exchange value of the dollar. Indeed, one member observed that the performane of prices might well prove to be betrer than was generally expected unless the exchange value of the dollar were to fall substantialy. A number of members commented that a limited dechne in the dollar migh have litte, it any, effect on domestic prices or in the extent of import penetration. 
looking ahead to the balance of the year, the members differed to some extent on an appropriate M1 target, but they generally concluded that it would not be clesirable in the current economic and financial environment to offset the recent spurt in $M 1$ by a slowing in the second half sufficient to bring M1 into the existing 4 to 7 percent longrun range. That would imply almost no growth month by month on average over the balance of the year. While the prospective behavior of M1 would remain subject to continuing uncertainties, the members believed that M1 velocity would probably move gradually toward a more usual or predictable pattern and that maintenance of the curent degree of reserve pressure would be associated with a reduction in M1 growth during the second half of the year to a moderate pace. Such growth was likely to be consistent with a pickup in the rate of economic expansion and continued containment of inflationary pressures. Accordingly, most of the members favored either raising the $M 1$ range that had been established in February for the year or rebasing the range from the fourth quarter of 1984 to the second quarter of 1985 , with a smaller increase or not change in the actual numerical range.

The members agreed that some shortfall in the growth of M1 from expectations, should it occur for a month or two, should not be resisted and might indeed be desirable in the context of acceptable economic performance. Conversely, a tendency for M1 growth to exceed expectations should be countered more promptly, at least in the view of some mombers, in light of the rapid earlief growth in tansaction balances. The members also felt that the behavior of the dollar in foreign exchange markets might well impose a sigm niffcant constraint - potentially in either direction - with regard to possible adjustments in the degree of reserve restraint over the weeks ahead.

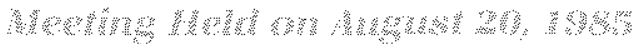

Though slowing from the quite rapid May-June pace, M1 had shown relatively strong growth since midyear; it in creased at an annual rate of about 9 pencent in July and data for early August indicated the likelihood of stronger growth in the current month. Thus, its expansion appeared to be well above the Committee's expectations for the June-toSeptember period. The strength in $M 1$ reflected an accelera" tion in other checkable deposits while demand deposits, though increasing little on balance, remained at high levels as the extraordinary surge of late spring in such deposits showed no signs of unwinding. Expansion in the broader aggregates slowed in July from the average pace over the previous two months, to annual rates of about $8-1 / 2$ percent for $M 2$ and $4-1 / 4$ percent for $M 3$.

Early in the intemeeting interval open market opemtions were directed at maintaining the existing degree of pressures on reserves. By early August, with M1 running well above the Committee's expectations at the time of the July meeting, and with $\mathrm{M} 2$ also on the high side, against the background of a weaker dollar and sustained economic activity, desk operations were conducted with a view to- ward more cautious provision of reserves.

Particular emphasis was given during the Committee's discussion to the prospect that domestic economic developments would depend importanty on international conditions, including the economic performance of industrial ized countries, the ability and willngness of developing countries to manage their foreign debt problems, the global energy situation, and the foreign exchange value of the dollar. The members continued to stress, as they had at previous meetings, the strongly adverse impact that foreign competition, fostered by a high value of the dollar in foreign exchange markets, was having on overall domestic economic activity and in particular on many manufactuting fums and on agriculture. Some members commented that the prospects for near-term improvement in the balance of trade seemed to be relatively remote.

Without provision of such funds [capital inflows] relatively willingly from abroad, pressures on domestic interest rates would be greater than otherwise. The members agreed that the transition to a lower trade deficit and a more sustainable pattern of international transactions generally, presumably accompanied by a lower dollar, would be greatly facilitated by substantial progress in reducing future deficits in the federal budget and by the avoidance of protectionist legislation that could have a highly unfavorable effect on international trade, on the ability of developing countries to resolve their external debt problems, and on the overall performance of the domestic economy. Several members noted that the risks associated with the underlying distortions and problems in the domestic economy and the persisting strains in domestic and international financial markets posed dilemmas that were not amenable to a monetary policy solution.

In the course of the Committee's discusston, a number of members emphasized the uncertainties surrounding the behavior of $\mathrm{M} 1$ and the down side risks they saw in the economy. Under prevailing circumstances, the surge in M1 growth might not have the usual inflationary implications. The demand for assets in M1 appeared to have been infuenced by the relatively low level of interest rates on market instruments and also on small time certificates of deposits, and the velocity of money seemed to be continuing to decline sharply. . It was also argued that the objective of achieving M1 growth within the Committee's longrun range might receive somewhat reduced emphasis, at least for a time, pending evaluation of further developments including the performance of the broader aggregates.

Other members expressed more concern that further M1 growth at rates substantially above the Commitiee's longrun range would have inflationary consequences over time. They noted the persisting strength of M1 in recent weeks, and should that continue, they felt that added reserve restraint would probably be desirable to bring M1 closer to the upper end, or within, the Committee's long-run range by the fourth quarter. Continued strength in M1 could also raise questions about the Commiltee's commitment to an 
anti-inflationary policy, with potentially adverse implications for inflationary expectations.

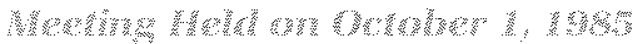

"The information reviewed at this meeting suggested that economic activity expanded in the third quarter at an annual rate of about 3 percent, compared with a rate of about 1 percent in the first half of the year. While the increase in total spending by domestic sectors was a litte weaker than in the first half, growth in domestic output was higher because the trade balance in the thind quarter apparently did not deteriorate further. Broad measures of prices and wages appeared to be rising at rates close to or somewhat below those recorded earlier in the year.

M1 growth surged in August to an annual rate just over 20 percent, reflecting exceptional strength in interest-bearing checkable deposits and relatively rapid expansion in other components. Data for the first haf of September suggested slower bul still substantial expansion in Ml. Thus, for the period from June to September $M 1$ was expanding at a rate well above the Committee's expectations, ard was at a level substantially higher than the path consistent with the Committee's range for the second half of the year. Reflecting the surge in M1, M2 accelerated in August to an annual fate of about $11-1 / 4$ percent and M3 also strengthened to a rate of about $8-1 / 2$ percent.

In the light of growth in the monetary aggregates especially M1 - continuing to exceed expectations, and with indications of a somewhat stronger tone in the economy as the intermeeting period progressed, open makket operations during the period were diected toward maintaining or slightly increasing the degree of reserve restraint that had been sought shortly before the meeting on August 20 . As a result, the level of adjustment plus seasonal borrowing rose somewhat on balance in the intermeeting interval, averaging about $\$ 515$ million in the latest reserve maintenance period ending September 25. Borrowing had been running substantially higher in recent days, however because of technical market conditions associated with a hurficane on the fast Coast and the end-of-quarter statement date.

Considerable attention was focused on the performance of the dollar in foreign exchange markets and the implica tions of possible changes in exchange rates for the balance of trade and the domestic economy. The nembers also reviewed developments relating to the foreign debt problems of less developed countries. In the course of discussion members recognized, as in previous meetings, that the extraordinary strength of the dollar earlier had contributed to the size of the trade deficit but they also emphasized the mportance of mantaining underlying confidence in the dolla:, given the dependence of the Lnited states for the time being on large capital inflows. It was noted that the possibility, while perhaps remote, of a precipitate continuing dedine in the value of the dollar would present a threat to the fuancial system and the economy because of its potential implications for higher interest rates and in flationary pressures, particularly in the absence of stronger budgetary restraint than had yet been achieved. Protectionist legislation would aggravate the potential difficulties. Consequently, it would be important that shifts in the value of the dollar be orderly.

In general , . it appeared increasingly doubtul that the targeted rate of $\mathrm{M} 1$ growth for the second half of the year as a whole could be reached without an inappropriately abrupt increase in reserve pressures and in interest rates. Growth in $\mathrm{M} 2$ and $\mathrm{M} 3$ was expected to remain roughly consistent with the target ranges for 1985 , and much slower growth in M1 - consistent with the upper end of its target - would in the view of mary members be acceptable and desirable, depending upon developments in the economy and financial matkets.

The members placed considerable emphasis on the need to judge the behavior of M1 in the context of the performance of the economy and the relatively moderate growth in the broader aggregates. Cumenty sensitive conditions in domestic and international financial markets and debt problems in some sectors of the economy such as agriculture were themselves a restraining force on the economy and argued against a policy course that might ontail appreciably higher interest rates in the short run. On the other hand, significant easing under immediately prevaling mar" ket circumstances would incur too much risk of prolonging undue growth in money and debt, possibly triggering an abrupt and exaggerated decline in the foreign exchange value of the dollar with disturbing implications for inflation and financial markets over time.

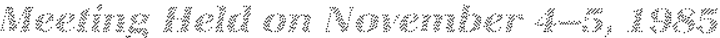

M1 appeared to have changed little on balance in October and may have declined slightly after several months of rapid expansion; but it remained well above the range set by the Committee in July of 3 to 8 percent at an annual rate for the period from the second quarter to the fourth quarter of the year. M2 and M3 apparently grew sluggishly during the month, reflecting a moderation in their nontransactions components as well as the weakness in M1. As a result, by October M2 apparently had moved to a level a bit below the upper end of its annual range, while M3 was still near the middle of its long-run range.

During the Committee's discussion of the economic situation and outlook, members commented that, on the whole, the latest infomation suggested a more sluggish economic performance than had been indicated earier. Nonetheless, several members felt that further economic expansion broadly in line with the staff forecast remained a reasonable expectation for the year ahead. In general, the members did not anticipate that any major sector of the economy would provide a strong fillip to the expansion. but they thought further growth was likely to be sustained by at least modest gains in several key sectors of the economy. At the same time, a number of members gave considerable emphasis to 
possible harbingers of a very sluggish economy. One member referred to the risk that the expansion itself might falter if persisting problems and financial strains in some sectors of the economy were not contained. The members recognized that under curent circumstances their forecasts were subject to a great deal of uncertainty, and particulat reference was made to the outlook for legishation to reduce the federal budget deficit and to the behavior of the dollar in foreign exchange markets.

While it was believed that the drop in the dollat since the G-5 meeting would tend to exert a positive effect on the economy by relieving pressures on export- and on mportsensitive industries, it was also pointed out that an unduly large and rapid depreciation could have the potential for unsetting economic consequences under present circumstances. One member commented that rising prices were already being reported for a few imported materials, appar" ently as a consequence of earlier reductions in the value of the dollar. The members were also concemed that, at a time when the deficit in the U.S. current account continued to require large net inflows of funds from abroad, any considerable reduction in the willingness of investors to accumulate dollar assets could exert upward pressure on domestic interest rates as well, with damaging implications for interest-sensitive sectors of the domestic economy and for several developing countries burdened by international debt problems.

The Committee tunned to a discussion of policy implementation for the forthcoming intermeeting period, and most of the members indicated that they were in favor of maintaining resenve conditions essentially unchanged, at least initially following today's meeting. The members took account, among other things, of an analysis which suggested that, given the prospect of modest expansion in economic activity during the fourth quarter, a steady degree of reserve pressure was likely to be associated with some pickup in growth of all the monetary aggregates over the remainder of the quarter from the reduced October pace.

As they hat at previous neetings, the members agreed that the behavior of M1 needed to be judged in the context of the perfomance of the economy and the fact that the broader aggregates were growing at rates within their ranges. Under prevailing circumstances, and unless the dollar declined sharply further, the strength of M1 thus far did not appear to suggest strong inflationary consequences. Thus, aggressive effots to reduce its growth beyond the slower pace that was already expected were deemed to be unwarranted, especially in light of the financial strains and other problems in some sectors of the economy and the attendant risks to the expansion itself. Accordingly, the members concluded that growth of M1 above its target range would be acceptable for the second half of the year. Growth of M2 and M3 within their long-run ranges continned to be appropriate.

In the Committee's discussion of possible intermeeting adjustments in the degree of Feserve restraint, members could foresee conditions that would call for either some easing or some tightening. Most of the members felt that policy implementation should be particularly alert to opportunities for some easing in light of the relatively sluggish growth in domestic economic activity and the favorable price perfomance, subject to the constmaint imposed by a desire to minimize the risk of inducing unacceptably faster growth in money and credit. It was also emphasized that account needed to be taken of the behavior of the dollar on foreign exchange markets in any policy adjustments.

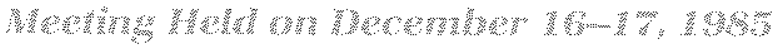

After declining slightly in October, M1 expanded at an annual rate of about 13 percent in November. Growth in $M 2$ and $\mathrm{M} 3$ continued quite moderate in November, at annual rates of about $6-1 / 2$ and 5 percent respectively. Through November, $M 1$ expanded at a pace well above the range set by the Commitlee in July of 3 to 8 percent at an annual rate over the period from the second quarter to the fourth quarter of the year; $M 2$ grew at a rate a bit below the upper limit of its range of 6 to 9 percent for the year and $M 3$ expanded at a rate near the midpoint of its range of 6 to 9-1/2 percent for 1985 .

Given expansion in the broader monetary aggregates at a pace close to the committee's expectations for the September-to-December period and within their longerrun ranges as well, and with account taken of economic and financial developments, open market operations during the intermeeting interval were directed toward maintaining approximately unchanged conditions of reserve availability.

The staff projections presented at this meeting had suggested that growth in real GNP would continue at a relatively modest pace in 1986, with the average unemployment rate and the rate of increase in prices during the coming year expected to change little from the rates in 1985. While the staff projection was seen as a plausible assessment of the outlook, several members emphasized that any current forecast was subject to a great deal of uncertainty. They referred, for example, to the difficuly of evaluating the potential impact of deficit reduction and tax reform legislation, and to the uncertainties surrounding the outlook for the U.S. trade balance.

'Turning to particular sectors of the econony, the members again underscored the variation in conditions among industries and their uneven contribution to current and prospective economic activity. Moderate growth was considered to be a reasonable expectation for many sectors of the economy. At the same time, the members expressed concem about the persisting problems and financial strains in some industries such as agriculture and a number of manufacturing and extractive businesses, notably those that competed actively with foreign producens.

With regard to the outlook for inflation, the members saw litte reason at this time to expect significant changes from the rates of increase experienced in 1985 . The reduced value of the dollar in foreign exchange markets would tend 
to exent some upward pressure on prices, but continued softness in wond commodity prices, especially oil, could have offsetting effects. Inflationary sentiment appeared to have diminished, as evidenced by the recent performance of the stock and bond markets, and with continuing compe" tition from abroad price competition could be expected to remain intense in many markets.

In the Committee's discussion of policy implementation for the period ahead, the members differed to some extent in their views conceming an appropriate degree of pressure on reserve positions. Some favored directing open market operations, at least initially, toward maintaining approximately unchanged conditions of reserve avalability. A majority, however, indicated a preference for moving toward implementing some slight easing of reserve conditions. Several also commented that decistons about the precise degree of reserve pressure should depend in part on whether the discount rate was reduced, and if so by how much.
While the final phase of deposit deregulation was expected to have litle net impact on monetary growth during the first quarter, the members recognized that the relation" ship between money and GNP remained subject to a great deal of uncertainty. They noted that the demand for Mt had deviated considerably from historical experience and that it was very difficult to predict when the unusual weakness in M1 velocily, which had been evident for several quarters, would be reversed and a more normal pattem would

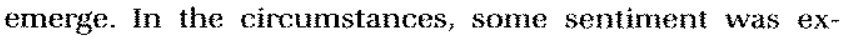
pressed for further reducing the emphasis on $\mathrm{M} 1$, but a majority of the members agreed that it should be retained as a guide among others for the conduct of monetary policy.

It was also suggested that the Committee's expectations with regard to the short-run growth of the aggregates be stated with less precision than in the past and that the behavior of M1, in particular, be evaluated in the context of other economic and financial developments, including the growth of the broader aggregates. 